\title{
Opção preferencial pelo corpo: à contribuição de Rubem Alves à Teologia da Libertação
}

\author{
Orientador: Abimar Oliveira de Moraes \\ Doutorando: Rainerson Israel Estevam de Luiz \\ Área de Concentração: Teologia Sistemático-Pastoral \\ Linha de Pesquisa: Fé e Cultura
}

Esta tese propõe uma reflexão, à luz das Escrituras Sagradas e da fé cristã, sobre a inovadora proposta para a Teologia da Libertação de Rubem Alves. Inicialmente, discute-se a Teologia Latino-Americana da Libertação (TdL), tentando investigar seus influxos das Ciências do Social (CdS), as quais forneceram o ferramental necessário para abordar o concreto-pensado sobre o qual a TdL teologizou. Pretende-se mostrar como Rubem Alves abriu mão de uma gramática marxista (realidade penúltima) e assumiu uma linguagem mais abrangente, humanista, interdisciplinar e holística sobre a liberdade e essência humana mediante uma interpretação inovadora de não apenas textos bíblicos e evangélicos, mas também de muitos poetas, teólogos, filósofos e uma gama ampla de outros pensadores sociais. A partir do diálogo interdisciplinar e suas próprias inquietudes e vivências dolorosas, Rubem Alves centralizou o corpo como a prioridade axiológica de seu "que-fazer" teológico da Libertação. Finalmente, propõe-se uma Teologia Libertação mais integral, poética e transcendente a partir do método pastoral tripartido "ver-julgar-agir" que, além de levar em conta a multidimensionalidade e complexidade da essência humana que o corpo expressa, assume uma linguagem mais dionisíaca e polifônica na busca pela libertação humana não só da servidão econômica, mas de todas as formas de repressão.

Palavras-chave: Teologia latino-americana da libertação. Rubem Alves. 